\title{
Prognostic factors in follicular lymphoma: A single institution study
}

\author{
N. JACOBI ${ }^{1}$, T.B. ROGERS ${ }^{2}$ and B.A. PETERSON ${ }^{2}$ \\ ${ }^{1}$ Department of Hematology, Oncology and Transplantation, University Clinic of Hamburg-Eppendorf, \\ Martinistr. 52, D-20246 Hamburg, Germany; ${ }^{2}$ University of Minnesota, Mayo Mail Code 480, \\ 420 Delaware Street S.E., Minneapolis, MN 55455, USA
}

Received November 16, 2007; Accepted February 12, 2008

\begin{abstract}
Recently developed prognostic models for follicular lymphoma have proven useful in predicting overall survival (OS), but most have used data from multiple centers. Our goal was to look at prognostic factors within a single institution.We conducted a retrospective study on 77 newly diagnosed patients with follicular lymphoma, focussing on clinical characteristics, symptom duration before diagnosis, pathologic findings, including grade, laboratory data, imaging studies at initial presentation and management. The study population was 53\% male. Ages ranged from 25 to 87 years (median 51). By Ann Arbor classification 4\% were stage I, $8 \%$ stage II, $18 \%$ stage III and $69 \%$ stage IV. Initial therapy was deferred in $39 \%$. The remaining patients received stageappropriate therapy. Survival was measured from time of diagnosis to death. Prognostic factors at initial diagnosis that were statistically significant in univariate log-rank comparisons of Kaplan-Meier survival curves were used to build a multivariate proportional hazard regression model of OS. Median OS for these patients was 10.3 years. OS differed only with high $(>12 \mathrm{~g} / \mathrm{dl})$ versus low $(<12 \mathrm{~g} / \mathrm{dl})$ hemoglobin $(\mathrm{p}=0.001)$ and in younger $(<60$ years) versus older ( $>60$ years) patients $(p=0.05)$, as indicated by univariate log-rank tests. Both hemoglobin and age were also significant in a multivariate proportional hazards analysis. Low hemoglobin and increased age were independent predictors of lower OS with hazard ratios of 6.6 (95\% CI, 2.2-20.1) and 3.7 (95\% CI, 1.2-11.7), respectively. Median survival for older patients who also had anemia was only 3.1 years. A test for interaction between age and hemoglobin was negative $(\mathrm{p}=0.35)$. The estimated hazard ratio for an older individual with low hemoglobin was 24.7 (95\% CI, 4.0-153.3). To assess the proportional hazards assumption we tested for an interaction between time and
\end{abstract}

Correspondence to: Dr Nicole Jacobi, Department of Hematology, Oncology and Transplantation, University Clinic of HamburgEppendorf, Goernestr. 10, D-20249 Hamburg, Germany

E-mail: jacob260@umn.edu

Key words: follicular lymphoma both age $(p=0.92)$ and hemoglobin $(p=0.66)$ and found no evidence against proportionality. A hemoglobin $<12 \mathrm{~g} / \mathrm{dl}$ and age $>60$ years at diagnosis are significant predictors of worse OS.

\section{Introduction}

Despite intensive research over decades, the biology of follicular lymphoma is still only partially understood. With the small exception of some stage I tumors, progression invariably occurs. Follicular lymphomas are indolent in nature and usually very responsive to chemotherapy. However, no combination of cytotoxic agents so far has been shown to alter overall survival (1-22), (Peterson BA, et al, Proc ASCO 16: abs. 14a, 1997). Since there is also no difference in rate nor time-point of transformation between initially treated versus untreated follicular lymphomas, a deferral of treatment is often recommended (23-25).

Follicular lymphoma shows a very variable disease course. Being able to identify a high-risk group in need for immediate aggressive chemotherapy is crucial. There have been numerous attempts to determine prognostic factors with this intention. The IPI, the International NHL Prognostic Factors Project, originally developed for aggressive NHLs has been tested on low-grade NHLs and found applicable although being critized for under-representing high-risk groups (26-35). The Italian Prognostic Index with 3 distinct risk groups was then developed. It resembles the IPI in many factors although it exchanges performance status for B-symptoms and includes the ESR. The ILI was consecutively tested against the IPI and was found to be more discriminative in most trials (36-38). There have been various other prognostic scores developed for low-grade NHLs or specifically for follicular lymphoma. Most notable are the scores of Leonard et al, Romaguera et al and Cameron et al (39-41). Among all scores available, there is often concordance regarding the factors Eastern Cooperative Oncology Group (ECOG) performance status, age and stage. The scores also variably utilize the predictors gender, number of extranodal sites, LDH, Hgb, B-symptoms, ESR and gut involvement $(9,39-42)$. The newest predictive score, the Follicular Lymphoma International Prognostic Index (FLIPI) has recently been published. This international cooperative group found the factors age, stage, $\mathrm{Hgb}$, number of nodal sites and LDH significant to form 3 prognostically distinct 
Table I. Patient characteristics.

\begin{tabular}{|c|c|c|c|c|c|}
\hline Parameter & Missing & No. available & $(\%)$ & 5-year survival (\%) & 10-year survival (\%) \\
\hline Gender & 0 & & & & \\
\hline Female & & 36 & 46.8 & 77.5 & 71.0 \\
\hline Male & & 41 & 53.2 & 86.3 & 66.1 \\
\hline Age & 0 & & & & \\
\hline$\leq 60$ & & 53 & 68.8 & 89.8 & 73.4 \\
\hline$>60$ & & 24 & 31.2 & 65.8 & 54.9 \\
\hline $\begin{array}{l}\text { Median symptom } \\
\text { duration (months) }\end{array}$ & 0 & & & & \\
\hline $\begin{array}{l}\text { Symptom duration } \\
\leq 3 \text { months }\end{array}$ & & 40 & 51.9 & 83.3 & 66.2 \\
\hline $\begin{array}{l}\text { Symptom duration } \\
>3 \text { months }\end{array}$ & & 37 & 48.1 & 81.4 & 69.7 \\
\hline ECOG & 0 & & & & \\
\hline 0 & & 47 & 61 & 83.1 & 68.9 \\
\hline 1 & & 30 & 39 & 81.2 & 64.9 \\
\hline 2 & & 0 & 0 & & \\
\hline 3 & & 0 & 0 & & \\
\hline 4 & & 0 & 0 & & \\
\hline $\mathrm{PMH}$ & 0 & & & & \\
\hline R.A. & & 4 & 5.2 & 100.0 & 50.0 \\
\hline Endocrine & & 9 & 11.7 & 88.9 & 74.1 \\
\hline Autoimmune & & 5 & 6.5 & 80.0 & 80.0 \\
\hline B-symptoms & 0 & & & & \\
\hline Yes & & 10 & 13.0 & 67.5 & 0 \\
\hline Fevers & & 5 & 6.5 & 80.0 & 80.0 \\
\hline Night sweats & & 7 & 9.1 & 68.6 & 68.6 \\
\hline Weight loss & & 8 & 10.4 & 71.4 & 71.4 \\
\hline No & & 67 & 87.0 & 84.7 & 73.3 \\
\hline LDH & 15 & & & & \\
\hline$>\mathrm{ULN}$ & & 8 & 12.9 & 85.7 & 85.7 \\
\hline$\leq \mathrm{ULN}$ & & 54 & 87.1 & a & a \\
\hline ESR & 59 & & & & \\
\hline$\geq 30 \mathrm{~mm} \mathrm{Hg}$ & & 3 & 16.7 & 33.3 & 33.3 \\
\hline$<30 \mathrm{~mm} \mathrm{Hg}$ & & 15 & 83.3 & 91.7 & 91.7 \\
\hline $\mathrm{Hgb}$ & 6 & & & & \\
\hline$<12 \mathrm{~g} / 1$ & & 14 & 19.7 & 57.7 & 43.3 \\
\hline$\geq 12 \mathrm{~g} / \mathrm{l}$ & & 57 & 80.3 & 75.8 & 75.8 \\
\hline Lymphocytes & 13 & & & & \\
\hline$<1000$ & & 13 & 20.3 & 91.7 & 61.1 \\
\hline$\geq 1000$ & & 51 & 79.9 & 79.3 & 62.7 \\
\hline Thrombocytes & 7 & & & & \\
\hline$<150$ & & 5 & 7.1 & 100 & 100 \\
\hline$\geq 150$ & & 65 & 92.9 & 84.3 & 69.2 \\
\hline Total protein & 41 & & & & \\
\hline$<6$ & & 0 & 0 & a & a \\
\hline$\geq 6$ & & 36 & 100 & 82.4 & 65.6 \\
\hline Albumin & 40 & & & & \\
\hline$<35$ & & 34 & 91.9 & 66.7 & 66.7 \\
\hline$\geq 35$ & & 3 & 8.1 & 87.7 & 69.8 \\
\hline
\end{tabular}


Table I. Continued.

\begin{tabular}{|c|c|c|c|c|c|}
\hline Parameter & Missing & No. available & $(\%)$ & 5-year survival (\%) & 10-year survival (\%) \\
\hline$\gamma$-globulin & 48 & & & & \\
\hline$<0.8$ & & 28 & 96.6 & 100 & 100 \\
\hline$\geq 0.8$ & & 1 & 3.4 & 91.0 & 80.8 \\
\hline LFT & 22 & & & & \\
\hline$>\mathrm{ULN}$ & & 48 & 87.3 & 80.0 & 80.0 \\
\hline$\leq \mathrm{ULN}$ & & 7 & 12.7 & 83.1 & 62.6 \\
\hline ß2-microglobulin & 65 & & & & \\
\hline$<3$ & & 12 & 100 & 90.0 & $90.0^{\mathrm{a}}$ \\
\hline$\geq 3$ & & 0 & 0 & a & a \\
\hline Nodal count & 12 & & & & \\
\hline$\geq 5$ & & 33 & 50.8 & 82.3 & 59.9 \\
\hline$<5$ & & 32 & 49.2 & 82.1 & 74.7 \\
\hline$\geq 3$ & & 22 & 33.8 & 87.1 & 69.2 \\
\hline$<3$ & & 43 & 66.1 & 73.0 & 60.8 \\
\hline Extranodal count & 12 & & & & \\
\hline$<2$ & & 52 & 80 & 84.7 & 68.9 \\
\hline$\geq 2$ & & 13 & 20 & 68.6 & 68.6 \\
\hline $\begin{array}{l}\text { Bone marrow } \\
\text { involvement }\end{array}$ & 1 & & & & \\
\hline Yes & & 55 & 72.4 & 76.0 & 61.1 \\
\hline No & & 21 & 27.6 & 95.0 & 71.3 \\
\hline Hepatomegaly & 12 & & & & \\
\hline Yes & & 1 & 1.5 & 100 & 100 \\
\hline No & & 64 & 98.5 & 83.9 & 66.7 \\
\hline Splenomegaly & 1 & & & & \\
\hline Yes & & 15 & 23.1 & 88.9 & 59.3 \\
\hline No & & 61 & 76.9 & 81.2 & 66.3 \\
\hline $\begin{array}{l}\text { Mediastinal } \\
\text { involvement }\end{array}$ & 12 & & & & \\
\hline Yes & & 17 & 26.1 & 81.3 & 60.9 \\
\hline No & & 48 & 73.9 & 82.4 & 66.3 \\
\hline $\begin{array}{l}\text { Retroperitoneal } \\
\text { involvement }\end{array}$ & 12 & & & & \\
\hline Yes & & 41 & 63.1 & 79.3 & 60.2 \\
\hline No & & 24 & 36.9 & 86.7 & 69.3 \\
\hline Blood involvement & 1 & & & & \\
\hline Yes & & 33 & 33.8 & 60.0 & 30.0 \\
\hline No & & 43 & 66.2 & 85.5 & 69.5 \\
\hline
\end{tabular}

andicates that relevant data are missing to determine 5- and 10-year overall survival.

\begin{tabular}{|c|c|c|c|c|c|}
\hline Stage and grade & Missing & No. available & $(\%)$ & 5-year survival (\%) & 10-year surv \\
\hline Ann Arbor stage & 5 & & & & \\
\hline I & & 3 & 4.2 & 100 & 100 \\
\hline II & & 6 & 8.3 & 100 & 100 \\
\hline III & & 13 & 18.1 & 91.7 & 61.1 \\
\hline IV & & 50 & 69.4 & 79.6 & 65.0 \\
\hline
\end{tabular}


Table I. Continued.

\begin{tabular}{|c|c|c|c|c|c|}
\hline Stage and grade & Missing & No. available & $(\%)$ & 5-year survival (\%) & 10 -year survival $(\%)$ \\
\hline Grade & 0 & & & & \\
\hline I & & 37 & 48.1 & 78.9 & 65.6 \\
\hline II & & 25 & 32.5 & 82.4 & 56.5 \\
\hline III & & 15 & 19.5 & 90.0 & 90.0 \\
\hline Treatment & Missing & No. available & $(\%)$ & 5-year survival (\%) & 10-year survival $(\%)$ \\
\hline \multicolumn{6}{|l|}{ Initial therapy } \\
\hline Watch and wait & 0 & 30 & 39.0 & 72.9 & 72.9 \\
\hline $\begin{array}{l}\text { Radiation (not } \\
\text { counted initial if } \\
\text { CHOP at same time) }\end{array}$ & 0 & 5 & 6.5 & 87.8 & 62.8 \\
\hline $\begin{array}{l}\text { Chemotherapy initial } \\
\text { (excluding WW and } \\
\text { radiation) check }\end{array}$ & 0 & 42 & 54.5 & 87.4 & 63.2 \\
\hline \multicolumn{6}{|l|}{ Chemotherapy regimen } \\
\hline $\begin{array}{l}\text { Prednisone or } \\
\text { dexamethasone initial }\end{array}$ & & 1 & 2.4 (of 42) & 100.0 & 100.0 \\
\hline Cytoxan initial & & 2 & 4.8 & 50.0 & 0.0 \\
\hline 2-CDA initial & & 2 & 4.8 & 100.0 & 0.0 \\
\hline $\begin{array}{l}\text { Cytoxan/prednisone } \\
\text { initial }\end{array}$ & & 1 & 2.4 & 100.0 & 100.0 \\
\hline $\begin{array}{l}\text { Chorambucil/ } \\
\text { prednisone initial }\end{array}$ & & 1 & 2.4 & 100.0 & 100.0 \\
\hline Fludarabine initial & & 1 & 2.4 & 0.0 & 0.0 \\
\hline CVP initial & & 5 & 11.9 & 80.0 & 80.0 \\
\hline $\begin{array}{l}\text { Fludarabine/ } \\
\text { CVP initial }\end{array}$ & & 1 & 2.4 & 100.0 & 100.0 \\
\hline $\begin{array}{l}\text { Cytoxan/adriamycin/ } \\
\text { etoposide initial }\end{array}$ & & 2 & 4.8 & 100.0 & 100.0 \\
\hline CHOP initial & & 24 & 57.1 & 89.1 & 76.4 \\
\hline $\begin{array}{l}\text { ProMACE-CYTA- } \\
\text { Bom initial }\end{array}$ & & 1 & 2.4 & 100.0 & 100.0 \\
\hline $\begin{array}{l}\text { Allogeneic trans- } \\
\text { plantation initial }\end{array}$ & & 1 & 2.4 & 100.0 & 100.0 \\
\hline $\begin{array}{l}\text { Adriamycin- } \\
\text { combinations initial }\end{array}$ & & 26 & 61.9 & 89.8 & 79.9 \\
\hline
\end{tabular}

\begin{tabular}{|c|c|c|c|c|}
\hline Response & No. available & $(\%)$ & 5-year survival (\%) & 10 -year survival $(\%)$ \\
\hline \multicolumn{5}{|l|}{ Initial response } \\
\hline WW & 30 & 100 & 72.9 & 72.9 \\
\hline WW continued & 12 & 40 & 100.0 & 100.0 \\
\hline $\begin{array}{l}\text { WW discontinued, } \\
\text { started treatment }\end{array}$ & 18 & 60 & 52.8 & 52.8 \\
\hline $\begin{array}{l}\text { Response to initial } \\
\text { treatment (chemo, } \\
\text { radiation, excluding } \\
\text { WW cont.) }\end{array}$ & 65 & 100 & 79.0 & 61.0 \\
\hline Unknown & 2 & 3.1 (of 65) & 100.0 & 100.0 \\
\hline Discontinuation & 2 & 3.1 & 100.0 & 100.0 \\
\hline
\end{tabular}


Table I. Continued.

\begin{tabular}{lcccc}
\hline Response & No. available & $(\%)$ & 5-year survival (\%) & 10-year survival (\%) \\
\hline CR & 28 & 43.1 & 88.7 & 69.9 \\
CR/BM known & 11 & 16.9 & 90.9 & 75.8 \\
PR & 24 & 36.9 & 89.8 & 62.9 \\
PR/BM known & 4 & 6.2 & 100.0 & 66.7 \\
Response <50\% & 2 & 3.1 & 100.0 & 100.0 \\
Stable disease & 1 & 1.5 & 100.0 & 100.0 \\
Progression & 6 & 9.2 & 0.0 & 0.0 \\
Transformation all & 12 & 15.6 (of 77) & 66.7 & 41.7 \\
patients (none initially) & & & & \\
\hline
\end{tabular}

groups. The score was subsequently tested on 919 patients and was shown to be valid (43).

We looked at prognostic factors for follicular lymphoma in patients from our institution. Among other factors, we wanted to test whether the prognosis of patients with follicular lymphoma is dependent on the length of symptoms before diagnosis and whether the course of the disease is determined by how long the 'Watch and Wait' approach lasts.

\section{Materials and methods}

Inclusion criteria. Patients diagnosed between 1992 and 2002 were selected from the Minnesota Cancer Surveillance System Database. All malignant tumors of Minnesota residents, newly diagnosed or reviewed in the Department of Pathology of the University of Minnesota, are reported to this Database. Selecting patients in this fashion ensured that the study sample comprised all patients diagnosed at the University of Minnesota during 1992 and 2002. During the timeframe given, 130 patients had been registered at the Database. Patient selection was performed according to the following inclusion criteria: follicular lymphoma grade I, II or III based on either the Working Formulation, the REAL or the WHO classification, treatment of the lymphoma at the University of Minnesota between 1/1/1992 and 12/31/2002. Fifty-three patients could not be included in the analysis for the following reasons: incorrect coding (12; CLL/SLL 2, nodular sclerosing Hodgkin's disease 1, diffuse large cell lymphoma 7, mantle cell lymphoma 1 , diffuse mixed small and large cell lymphoma 1), inadequate initial data (18), not followed (15), visit only for consultation (2), lost patient charts (2) and lack of follow-up (2). This retrospective study was approved by the Institutional Review Board of the University of Minnesota.

Patient characteristics and initial staging. Patients underwent a complete history and physical examination, including an assessment of B-symptoms and their performance status through ECOG classification. An evaluation of symptom duration before first diagnosis was undertaken. We collected data on patients' history of rheumatological, autoimmune and endocrine disorders. Laboratory testing (CBCDP, ESR, AST, ALT, Alk. Phos., T-Bili, total protein, albumin, $\gamma$-globulin) and computerized tomographies (CT's) of chest, abdomen and pelvis were documented. A bone marrow biopsy was done in 71 patients. If available, B2-microglobulin, cytogenetic and molecular rearrangement studies were included. Ten patients had a documented B2-microglobulin level. Fiftynine patients had an LDH check at initial diagnosis. Biopsies were taken from the following sites: scalp (1), forehead (3), neck (28), thyroid (1), parotid (2), supraclavicular (7), axilla (7), mesenteric/abdominal (3), colon/small intestine (1), retroperitoneal (3), epitrochlear (1), inguinal (13), thigh mass (1), bone/soft tissue (1), unknown (6). All bone marrow aspirates, biopsies and lymph node biopsies were reviewed at our institution for confirmation of correct diagnosis and grading. The Ann Arbor system was utilized for staging. Nodal sites were counted as follows: cervical, supraclavicular, axillary, mediastinal, pleural effusion, intrapulmonary, celiac/ gastrohepatic ligament, portocaval/porta hepatis/portocephalic, liver, mesenteric, spleen, splenic veins, retroperitoneal above renal veins, retroperitoneal below renal veins, pelvis, inguinal/ femoral (if applicable bilaterally). Spleen was included in nodal counts. Bone marrow involvement was judged as extranodal involvement.

Complete remission, $\mathrm{CR}$, was defined as no evidence of disease clinically nor on CT of chest/abdomen/pelvis. We subdivided the patients in CR into 2 groups depending on whether a bone marrow biopsy had been done or not. Partial remission, $\mathrm{PR}$ was defined as $\geq 50 \%$ reduction of measurable disease for at least 1 month. Again, we differentiated whether a bone marrow biopsy had been undertaken. Failure was defined as any other response such as stable disease, mixed response, progression, death including death from treatment toxicity. Survival was measured from time of first diagnosis until death.

Treatments. One of the 77 patients, 3 (3.9\%) with follicular lymphoma stage I were treated with radiation in curative intent. One of the $77(1.3 \%)$ also started with radiation with clinical stage IA. However, a bone marrow biopsy had not been performed due to morbid obesity. Two of the 77 had more advanced stages of follicular lymphoma and nevertheless initially treated with radiation. Of the 77 patients, 30 (39\%) did not receive initial treatment but were monitored only ('Watch \& Wait'). The remaining 41 patients expressed symptoms that determined the initiation of chemotherapy. 
Single agent therapy (cytoxan, chlorambucil) was started in 2/77 (2.6\%). Monotherapy with either prednisone or dexamethasone was begun in 1/77 (1.3\%), 2/77 (2.6\%) received 2-CDA, 6/77 (7.8\%) received CVP initially, 1/77 (1.3\%) cytoxan/prednisone and 1/77 (1.3\%) chlorambucil/prednisone. One of the 77 (1.3\%) underwent monotherapy with fludarabine, $1 / 77(1.3 \%)$ received a treatment combination of fludarabine/ CVP, 2/77 (2.6\%) were treated with cytoxan/adriamycin/ etoposide, 22/77 (28.6\%) received CHOP initially, 2/77 (2.6\%) also received radiation immediately following CHOP treatment, $1 / 77(1.3 \%)$ was started on ProMACE-CytaBOM and $1 / 77(1.3 \%)$ immediately underwent allogeneic transplantation.

Statistical analysis. The SAS statistical package (version 8e) was used for the analysis of all data. Survival was measured from first diagnosis to death from any cause. Not all patients had complete data on the prognostic factors we examined (Table I). Survival curves were estimated by the method of Kaplan-Meier. Statistically significant prognostic factors at initial diagnosis were then compared in a multivariate proportional hazard regression model.

\section{Results}

Patient characteristics. Table I summarizes the characteristics of the 77 patients included in this study. The majority of patients $(69.4 \%)$ presented with follicular lymphoma stage IV of the Ann Arbor classification. Nearly half of the patients (48.1\%) had grade I. The median follow-up for all patients was 5.56 years. The median overall survival of the study patients was 10.3 years. Of the 30 patients who were monitored only, $14(46.7 \%)$ had not started treatment by the end of the observation time of the study. Of all patients, $42.9 \%$ achieved a complete response with initial chemotherapy or radiation. Adriamycin-containing regimens were most commonly used $(31.2 \%)$. Of all patients, $15.6 \%$ underwent transformation during the course of their disease.

Tables II-IV categorize the patients of this study according to the prognostic indices IPI, Italian Prognostic Index and FLIPI. The concordance among the different prognostic scores is difficult to assess as there is missing data for the ILI score in 68 out of the 77 patients. In contrast to the IPI, the FLIPI places the majority of patients into the intermediate group. With $30.6 \%$ of patients being in the high-risk group, it exhibits a significant difference to the IPI which only places $9.6 \%$ in the high intermediate group and none of the patients in the high-risk group.

Only the 2 factors age $>60$ years and $\mathrm{Hgb}<12 \mathrm{~g} / \mathrm{dl}$ changed the overall survival significantly (Table V). Neither the duration of symptoms before diagnosis nor the interval length of the 'Watch and Wait' period had an important impact on overall survival. Of note, the Kaplan-Meier survival curves underestimate the mean survival time in the 2 groups looking at risk factors age and $\mathrm{Hgb}$ independently as the last patients were censored.

As shown in Table VI, both factors were also independent predictors of lower overall survival in a multivariate proportional hazard analysis. A test for interaction between age and hemoglobin was negative $(\mathrm{p}=0.35)$.
Table II. Prognostic Index IPI.

\begin{tabular}{lcr}
\hline Risk & Count & $(\%)$ \\
\hline Low & 29 & 55.8 \\
Low intermediate & 18 & 34.6 \\
High intermediate & 5 & 9.6 \\
High & 0 & 0 \\
\hline
\end{tabular}

Missing data in 25 patients.

Table III. Italian Prognostic Index.

\begin{tabular}{lcc}
\hline Risk & Count & $(\%)$ \\
\hline Low & 6 & 66.7 \\
Intermediate & 1 & 11.1 \\
High & 2 & 22.2 \\
\hline
\end{tabular}

Missing data in 68 patients.

Table IV. FLIPI.

\begin{tabular}{lcc}
\hline Risk & Count & $(\%)$ \\
\hline Low & 13 & 26.5 \\
Intermediate & 21 & 42.9 \\
High & 15 & 30.6 \\
\hline
\end{tabular}

Missing data in 28 patients.

Table V. Significant univariate log-rank tests.

\begin{tabular}{lcc}
\hline Prognostic factor & Log-rank test & Wilcoxon \\
\hline Age $>60$ years & 0.0500 & 0.0514 \\
$\mathrm{Hgb}<12 \mathrm{~g} / \mathrm{dl}$ & 0.0010 & 0.0008 \\
\hline
\end{tabular}

The conclusions of the model were supported by the estimated average survival times for each of the four risk groups, as determined by stratified Kaplan-Meier curves. The survival for patients $>60$ years who also had anemia was 3.1 years, 4 out of 77 patients fit into this group.

Table VII illustrates how strongly the 4 different combinations of the the prognostic factors age and $\mathrm{Hgb}$ change the mean and median overall survival. The 2 groups that show either one of the 2 prognostic factors did not reach the $50 \%$ 
Table VI. Multivariate proportional hazard analysis.

\begin{tabular}{lccc}
\hline $\begin{array}{l}\text { Prognostic } \\
\text { factor }\end{array}$ & $\begin{array}{c}\text { Hazard } \\
\text { ratio }\end{array}$ & $95 \% \mathrm{CI}^{\mathrm{a}}$ & P-value \\
\hline Age $>60$ years & 6.6 & $2.2-20.1$ & 0.0231 \\
$\mathrm{Hgb}<12 \mathrm{~g} / \mathrm{dl}$ & 3.7 & $1.2-11.7$ & 0.0008 \\
$\mathrm{Age}>60$ years and & $24.7^{\mathrm{b}}$ & $4.0-153.3^{\mathrm{b}}$ & \\
$\mathrm{Hgb}<12 \mathrm{~g} / \mathrm{dl}$ & & & \\
\hline
\end{tabular}

${ }^{\mathrm{a}} \mathrm{CI}$, confidence interval. ${ }^{\mathrm{b}} \mathrm{Calculated}$ from estimated additive Cox model.

Table VII. Impact of the 4 possible combinations of the 2 prognostic factors on mean and median overall survival (Fig. 1).

\begin{tabular}{lccc}
\hline $\begin{array}{l}\text { Risk factor } \\
\text { combination }\end{array}$ & $\begin{array}{c}\text { Mean OS } \\
\text { (months) }\end{array}$ & $\begin{array}{c}\text { Median OS } \\
\text { (months) }\end{array}$ & $\begin{array}{c}\text { No. of } \\
\text { patients }\end{array}$ \\
\hline
\end{tabular}

\begin{tabular}{lccc}
\hline $\begin{array}{l}\text { Age }<60 \text { years and } \\
\mathrm{Hgb}\end{array}$ & $96.3 \mathrm{~g} / \mathrm{dl}$ & Not reached & 38 \\
Age $>60$ years and & 73.7 & Not reached & 19 \\
$\mathrm{Hgb} \leq 12 \mathrm{~g} / \mathrm{dl}$ & & & \\
Age $\leq 60$ years and & 92.7 & 123.2 & 10 \\
$\mathrm{Hgb}<12 \mathrm{~g} / \mathrm{dl}$ & & & \\
Age $>60$ years and & 33.0 & 37.7 & 4 \\
$\mathrm{Hgb}<12 \mathrm{~g} / \mathrm{dl}$ & & & \\
\hline
\end{tabular}

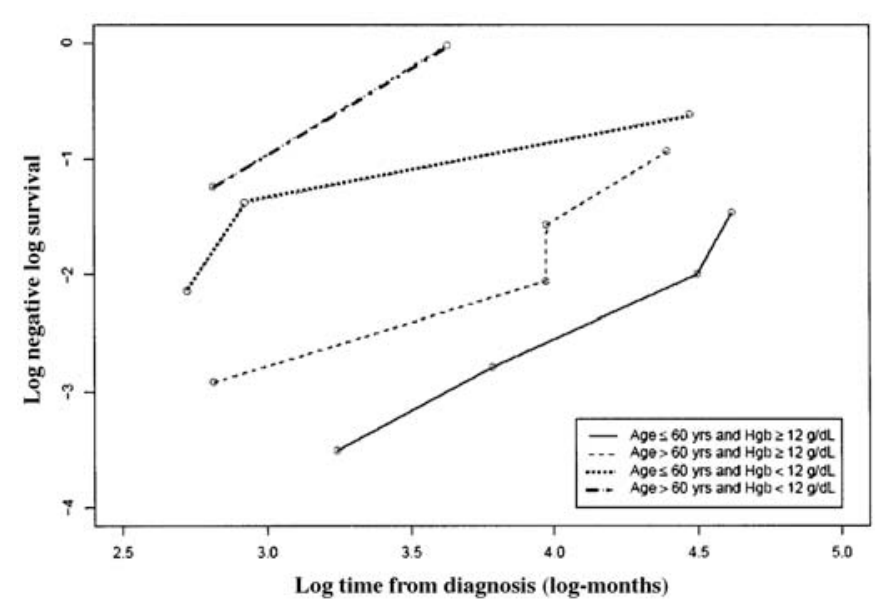

Figure 1. Proportional hazards assumption assessment.

median survival mark. Table VIII illustrates that the prognostic factor $\mathrm{Hgb}<12 \mathrm{~g} / \mathrm{dl}$ has a greater impact on mean and median overall survival than age $>60$ years.
Table VIII. Testing the proportional hazards assumption (Fig. 2).

\begin{tabular}{lc}
\hline Prognostic factor & P-value \\
\hline Time $x$ age $<60$ years & 0.92 \\
Time $x \mathrm{Hgb}<12 \mathrm{~g} / \mathrm{dl}$ & 0.66 \\
Proportionality test & 0.91 \\
\hline
\end{tabular}

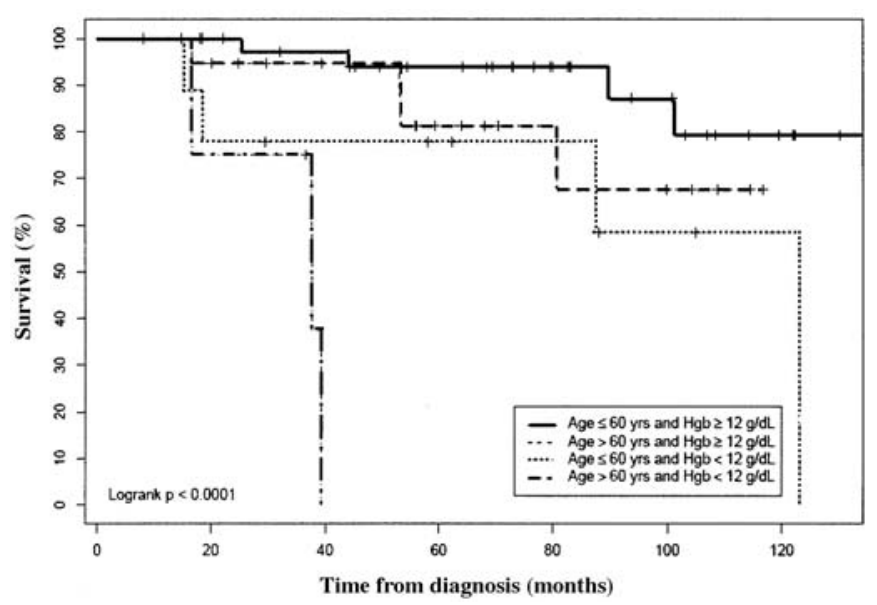

Figure 2. Overall survival.

An assessment of the proportional hazards assumption was undertaken by testing for an interaction between time and both age and hemoglobin. We found no evidence against proportionality (Fig. 1).

\section{Discussion}

Being able to identify a subset of patients with follicular lymphoma who will benefit from early aggressive treatment has been the goal of many studies in the past. The mainstay of these observational studies was the determination of prognostic factors that were then built into a predictive score. The Italian Lymphoma Intergroup included the factors LDH, age, B-symptoms, ESR and number of extranodal sites into their Italian Prognostic Index. The recently published Follicular Lymphoma International Prognostic Index (FLIPI), found the factors age, Ann Arbor stage, Hgb, number of nodal areas and LDH level to be prognostically significant. Both prognostic scores were based on large multicenter data collections. Our study reviewed data from our institution only. The lower number of patients could explain why some of the factors, significant in the Italian Prognostic Index and the FLIPI, were not statistically important in our data analysis. The strength of the current study lies in the detailed documentation of patient characteristics at initial presentation. With the knowledge of symptom duration before first diagnosis, we even provided a notion of the patient's natural course of disease. The Italian Prognostic Index analysed the pathology slides according to the updated Kiel classification. As this classification does not 
subdivide the centroblastic-centrocytic group into 2 subgroups comparable to grades I and II of the REAL classification, grading was not undertaken. Both groups included follicular large cell lymphoma. The percentage of grade III lymphoma is not given in the Italian Prognostic Index. This makes a comparison with our study sample difficult. The FLIPI included 9\% grade III follicular lymphomas. Our sample with $19.5 \%$ had nearly double the amount of grade III follicular lymphomas. Follicular large lymphomas have long been regarded as a separate entity as their nature is less indolent than grade I and II follicular lymphomas. The FLIPI did not review the pathology slides of their study subjects centrally. In our study, all bone marrow aspirates and biopsies as well as lymph node biopsies were reviewed. This practice ensured avoidance of differential misclassification. We also found that of the original 130 patients from the Minnesota Cancer Surveillance System Database, 12 (9.2\%) had to be excluded due to wrong diagnoses. Choosing this database also provided us with a representative sample of the population of Minnesota as all patients with follicular lymphoma seen at the University of Minnesota are entered into this system. The FLIPI looked at patients from multiple centers that had been entered into several trials. It would be important to know how the study patients differed in characteristics from those patients with follicular lymphoma that had not been included in a study. A significant difference between study- and non-study patients could have an important influence on resulting prognostic factors and overall survival. The FLIPI was based on data from only $1795 / 4167(43.1 \%)$ of the original patients due to missing data. Although the score was validated on a second sample of patients where the data necessary for the prognostic score was available, there is still a question of selection bias with influence on the outcomes prognostic factors and survival. This can only be answered in a prospective setting. Our data correspond partially with the FLIPI as age $>60$ and $\mathrm{Hgb}<12 \mathrm{~g} / \mathrm{l}$ are prognostic factors in both studies. We did not find the Ann Arbor stage, the number of nodal areas or the serum LDH level to be statistically significant for overall survival. This could have been due to our smaller study sample. It is of interest that many of the prognostic scores published in recent years share certain prognostic factors. Yet it still has to be proven that patients with those prognostic factors will actually benefit from a more aggressive treatment up-front. In recent years attempts have been made to also include prognostic factors on the molecular level. Most recently, Björck et al added molecular factors to the FLIPI and found that CCNB or cyclin B1 was an independent prognostic factor in addition to the original parameters of the FLIPI score (44). It was discovered with gene-expression profiling that non-malignant tumor-infiltrating immune cells were important prognostic factors independent of clinical characteristics of the patients $(45,46)$. It can be anticipated that clinical features will play a less important role in predicting the prognosis of follicular lymphoma in light of new molecular factors that will likely be discovered in the near future.

\section{References}

1. Jones SE, Rosenberg SA, Kaplan HS, Kadin ME and Dorfman RF: Non-Hodgkin's lymphoma: II. Single agent chemotherapy. Cancer 30: 31-38, 1972 .
2. Solal-Celigny P, Brice P, Brousse N, Caspard H, Bastion Y, Haioun C, Bosly A, Tilly H, Bordessoule D, Sebban C, Harousseau JL, Morel P, Dupas B, Plassart F, Vasile N, Fort N and Leporrier M: Phase II trial of fludarabine monophosphate as first-line treatment in patients with advanced follicular lymphoma: a multicenter study by the Groupe D'Etude des Lymphomes de l'Adulte. J Clin Oncol 14: 514-519, 1996.

3. Gupta R and Lister T: Curent management of follicular lymphoma. Current Opin Oncol 8: 360-365, 1996.

4. Lister TA, Cullen MH, Beard ME, Brearley RL, Whitehouse JM, Wrigley PF, Stansfeld AG, Sutcliffe SB, Malpas JA and Crowther D: Comparison of combined and single-agent chemotherapy in non-Hodgkin's lymphoma of favourable histological type. Br Med J 1: 533-537, 1978.

5. Glick JH, Barnes JM, Ezdinli EZ, et al: Nodular mixed lymphoma: results of a randomized trial failing to confirm prolonged disease-free survival with COPP chemotherapy. Blood 58: 920-925, 1981.

6. Dan BW, Dahlberg S, Nathwani BN, et al: Long term follow-up of patients with low-grade malignant lymphomas treated with doxorubicin-based chemotherapy or chemoimmunotherapy. J Clin Oncol 11: 644-651, 1993.

7. Peterson BA: Current treatment of follicular low-grade lymphomas. Semin Oncol 26 (Suppl. 14): S2-S11, 1999.

8. Peterson BA, Petroni GR, Frizzera G, Barcos M, Bloomfield CD, Nissen NI, Hurd DD, Henderson ES, Sartiano GP, Johnson JL, Holland JF and Gottlieb AJ: Prolonged single-agent versus combination chemotherapy in indolent follicular lymphomas: a study of the cancer and leukemia group B. J Clin Oncol 21: 5-15, 2003.

9. Rodriguez J, McLaughlin P, Hagemeister FB, Fayad L, Rodriguez MA, Santiago M, Hess M, Romaguera J and Cabanillas F: Follicular large cell lymphoma: an aggressive lymphoma that often presents with favorable prognostic features. Blood 93: 2202-2207, 1999.

10. Zinzani PL, Pulsoni A, Perroti A, Soverini S, Zaja F, De Renzo A, Storti S, Lauta VM, Guardigni L, Gentilini P, Tucci A, Molinari AL, Gobbi M, Fallini B, Fattori PP, Ciccone F, Allinari L, Martelli M, Pileri S, Tura S and Baccarani M: Fludarabine plus Mitoxantrone with and without Rituximab versus CHOP with and without Rituximab as front-line treatment for patients with follicular lymphoma. J Clin Oncol 22: 2654-2661, 2004.

11. Ghielmini M, Schmitz SF, Cogliatti SB, Pichert G, Hummerjohann J, Waltzer U, Fey MF, Betticher DC, Martinelli G, Peccatori F, Hess U, Zucca E, Stupp R, Kovacsovics T, Helg C, Lohri A, Bargetzi M, Vorobiof D and Cerny T: Prolonged treatment with rituximab in patients with follicular lymphoma significantly increases event-free survival and response duration compared with the standard weekly $\mathrm{x} 4$ schedule. Blood 103: 4416-4423, 2004.

12. Ghobrial I and Witzig T: Radioimmunotherapy: a new treatment modality for B-cell non-Hodgkin's lymphoma. Oncology 18: 623-630, 2004.

13. Brice P, Bastion Y, Lepage E, Brousse N, Haioun C, Moreau P, Straetmans N, Tilly H, Tabah I and Solal-Celigny P: Comparison in low-tumor-burden follicular lymphomas between an initial no-treatment policy, prednimustine, or interferon alfa: a randomized study from the Groupe d'Etude des Lymphomes Folliculaires. Groupe d'Etude des Lymphomes de l'Adulte. J Clin Oncol 15: 1110-1117, 1997.

14. Smalley RV, Andersen JW, Hawkins MJ, Bhide V, O'Connell MJ, Oken MM and Borden EC: Interferon alfa combined with cytotoxic chemotherapy for patients with non-Hodgkin's lymphoma. N Engl J Med 19: 1336-1341, 1992.

15. Aviles A, Duque G, Talavera A and Guzman R: Interferon alpha $2 \mathrm{~b}$ as maintenance therapy in low-grade malignant lymphoma improves duration of remission and survival. Leuk Lymphoma 20: 495-499, 1996.

16. Hsu FJ, Caspar CB, Czerwinski D, Kwak LW, Liles TM, Syrengelas A, Taidi-Laskowski B and Levy R: Tumor-specific idiotype vaccines in the treatment of patients with B-cell lymphoma - long-term results of a clinical trial. Blood 89: 3129-3135, 1997.

17. Veelken H: Active immunotherapy in follicular lymphoma. Semin Cancer Biol 13: 241-247, 2003.

18. Chanan-Khan A and Czuczman MS: Bcl-2 antisense therapy in B-cell malignant proliferative disorders. Curr Treat Options Oncol 5: 261-267, 2004. 
19. MacManus MP and Hoppe RT: Is radiotherapy curative for stage I and II low-grade follicular lymphoma? Results of a longterm follow-up study of patients treated at Stanford University. J Clin Oncol 14: 1282-1290, 1996.

20. Aviles A, Delgado S, Fernandez R, Talavera A, Neri N and Huerta-Guzman J: Combined therapy in advanced stages (III and IV) of follicular lymphoma increases the possibility of cure: results of a large controlled clinical trial. Eur J Haematol 68: 144-149, 2002.

21. Van Besien K, Loberiza FR Jr, Bajorunaite R, Armitage JO, Bashey A, Burns LJ, Freytes CO, Gibson J, Horowitz MM, Inwards DJ, Marks DI, Martino R, Maziarz RT, Molina A, Pavlovsky S, Pecora AL, Schouten HC, Shea TC, Lazarus HM, Rizzo JD and Vose JM: Comparison of autologous and allogeneic hematopoietic stem cell transplantation for follicular lymphoma. Blood 102: 3521-3529, 2003.

22. Jones SE: Follicular lymphoma - do no harm. Cancer Treat Rep 70: 1055-1058, 1986.

23. Horning SJ and Rosenberg SA: The natural history of initially untreated low-grade non-Hodgkin's lymphomas. N Engl J Med 311: 1471-1475, 1984

24. Young RC, Longo DL, Glatstein E, Ihde DC, Jaffe ES and DeVita VT Jr: The treatment of indolent lymphomas: watchful waiting $v$ aggressive combined modality treatment. Semin Hematol 25 (Suppl. 2): S11-S16, 1988.

25. Advani R, Rosenberg SA and Horning SJ: Stage I and II follicular non-Hodgkin's lymphoma: long-term follow-up of no initial therapy. J Clin Oncol 22: 1454-1459, 2004.

26. The International Non-Hodgkin's Lymphoma Prognostic Factors Project: A predictive model for aggressive non-Hodgkin's lymphoma. The International Non-Hodgkin's Lymphoma Prognostic Factors Project. N Engl J Med 329: 987-994, 1993.

27. The Non-Hodgkin's Lymphoma Classification Project: A clinical evaluation of the International Lymphoma Study Group classification of non-Hodgkin's lymphoma. Blood 89: 3909-3918, 1997.

28. Lopez-Guillermo A, Montserrat E, Bosch F, Terol MJ, Campo E and Rozman C: Applicability of the International Index for aggressive lymphomas to patients with low-grade lymphoma. J Clin Oncol 12: 1343-1348, 1994.

29. Bastion Y and Coiffier B: Is the International Prognostic Index for aggressive lymphoma patients useful for follicular lymphoma patients? J Clin Oncol 12: 1340-1342, 1994.

30. Aviles A: The International Index is not useful in the classification of low-grade lymphoma. J Clin Oncol 12: 2766-2768, 1994.

31. Aviles A, Neri N, Cuadra I, Alvarado I, Fernandez R, Calva A and Huerta-Guzman J: Lack of prognostic factors in follicular lymphoma. Leuk Lymphoma 44: 143-147, 2003.

32. Foussard C, Desablens B, Sensebe L, Francois S, Milpied N, Deconinck E, Delwail V, Dugay J, Lamy T, Ghandour C, Le Mevel A, Maisonneuve H, Casassus P and Colombat P: Is the International Prognostic Index for aggressive lymphomas useful for low-grade lymphoma patients? Applicability to stage III-IV patients. The GOELAMS Group, France. Ann Oncol 8 (Suppl. 1): S49-S52, 1997.

33. Hermans J, Krol AD, van Groningen K, Kluin PM, KluinNelemans JC, Kramer MH, Noordijk EM, Ong F and Wijermans PW: International Prognostic Index for aggressive non-Hodgkin's lymphoma is valid for all malignancy grades. Blood 86: 1460-1463, 1995 .

34. Bastion Y, Berger F, Bryon PA, Felman P, Ffrench M and Coiffier B: Follicular lymphomas: assessment of prognostic factors in 127 patients followed for 10 years. Ann Oncol 2 (Suppl. 2): S123-S129, 1991.
35. Coiffier B, Gisselbrecht C, Vose JM, Tilly H, Herbrecht R, Bosly A and Armitage JO: Prognostic factors in aggressive malignant lymphomas: description and validation of a prognostic index that could identify patients requiring a more intensive therapy. The Groupe d'Etudes des Lymphomes Agressifs. J Clin Oncol 9: 211-219, 1991.

36. Federico M, Vitolo U, Zinzani PL, Chisesi T, Clo V, Bellesi G, Magagnoli M, Liberati M, Boccomini C, Niscola P, Pavone V, Cuneo A, Santini G, Brugiatelli M, Baldini L, Rigacci L and Resegotti L: Prognosis of follicular lymphoma: a predictive model based on a retrospective analysis of 987 cases. Intergruppo Italiano Linfomi. Blood 95: 783-789, 2000.

37. Perea G, Altes A, Montoto S, Lopez-Guillermo A, Bosch F, Jimenez M, Esteve J, Domingo E, Ribera JM, Pedro C, Martino R, Briones J, Sureda A, Brunet S, Sierra J and Montserrat E: International and Italian prognostic indices in follicular lymphoma. Haematologica 88: 700-704, 2003.

38. Maartense E, Le Cessie S, Kluin-Nelemans HC, Kluin PM, Snijder S, Wijermans PW and Noordijk EM: Age-related differences among patients with follicular lymphoma and the importance of prognostic scoring systems: analysis from a population-based non-Hodgkin's lymphoma registry. Ann Oncol 13: $1275-1284,2002$.

39. Leonard RC, Hayward RL, Prescott RJ and Wang JX: The identification of discrete prognostic groups in low-grade nonHodgkin's lymphoma. The Scotland and Newcastle Lymphoma Group Therapy Working Party. Ann Oncol 2: 655-662, 1991.

40. Romaguera JE, McLaughlin P, North L, Dixon D, Silvermintz KB, Garnsey LA, Velasquez WS, Hagemeister FB and Cabanillas F: Multivariate analysis of prognostic factors in stage IV follicular low-grade lymphoma: a risk model. J Clin Oncol 9: 762-769, 1991 .

41. Cameron DA, Leonard RC, Mao JH and Prescott RJ: Identification of prognostic groups in follicular lymphoma. The Scotland and Newcastle Lymphoma Group Therapy Working Party. Leuk Lymphoma 10: 89-99, 1993.

42. Rodriguez J, Cabanillas F, McLaughlin P, Swan F, Rodriguez M, Hagemeister $F$ and Romaguera J: A proposal for a simple staging system for intermediate grade lymphoma and immunoblastic lymphoma based on the 'tumor score'. Ann Oncol 3: 711-717, 1992.

43. Solal-Celigny P, Roy P, Colombat P, White J, Armitage JO, Arranz-Saez R, Au WY, Bellei M, Brice P, Caballero D, Coiffier B, Conde Garcia E, Doyen C, Federico M, Fisher RI, Garcia-Conde JF, Guglielmi C, Hagenbeek A, Haioun C, Le Blanc M, Lister AT, Lopez-Guillermo A, McLaughlin P, Milpied N, Morel P, Mounier N, Proctor SJ, Rohatiner A, Smith P, Soubeyran P, Tilly H, Vitolo U, Zinzani PL, Zucca E and Montserrat E: Follicular lymphoma international prognostic index. Blood 104: 1258-1265, 2004.

44. Björck E, Ek S, Landgren O, et al: High expression of cyclin B1 predicts a favorable outcome of patients with follicular lymphoma. Blood 105: 2908-2915, 2004

45. Dave SS, Wright G, Tan B, et al: Prediction of survival in follicular lymphoma based on molecular features of tumorinfiltrating immune cells. N Engl J Med 351: 2159-2169, 2004.

46. Rohatiner AZ, Gregory WM, Peterson B, et al: Meta-analysis to evaluate the role of interferon in follicular lymphoma. J Clin Oncol 23: 2215-2223, 2005. 